\title{
The Integration of Character Education in Learning Indonesian Subject at Elementary School
}

\author{
Rosmalah $^{1}$, Abd. Hafid ${ }^{2}$, Rukayah ${ }^{3}$ \\ \{rosmala@unm.ac.id ${ }^{1}$ \} \\ ${ }^{1,2,3}$ Pendidikan Guru SekolahDasar, Universitas Negeri Makassar, Makassar, Indonesia
}

\begin{abstract}
: the industrial revolution 4.0 had brought a rapid change including the use of technology in education. Character education became a human wisdom tool in dealing with the flow of changes that affect the human's mentality. Students must be provided from the beginning about the value of national character, it could be done through the integration of character values in learning, especially Indonesian language learning in elementary school (SD). This study aimed to integrate the character education into learning Indonesian in elementary school, specifically there were two main points of study, those are (1) identifying the appropriate character values to be integrated into Indonesian subjects in elementary school (2) integrating character values into Indonesian learning in elementary school. The research design was descriptive qualitative that aimed to present research findings through more detailed narratives. The data sources were obtained through documentation, that was obtained from Indonesian primary school learning books, observation, observing the students behavior in the classroom, and teacher interviewed. The research instrument referred to strengthening character education (PPK) of the ministries of education and culture. Based on the analysis, the results were (1) The appropriate character values that was integrated into the Indonesian were: tolerance, mutual cooperation, honesty, responsibility, and being autonomous; (2) integrating character values into Indonesian learning could be done through teaching media, learning models, and authentic assessments.
\end{abstract}

Keywords :character education, Indonesian learning material in primary school

\section{Introduction}

In welcoming the industrial revolution 4.0 that is marked by the emergence of supercomputers, unmanned vehicles, smart robots and genetic engineering. It is considered in enabling humans to optimize their brain function. However, there are some aspects that needs to be prepared so that thefourth generation of industrial revolution does not have a negative impact on the humans role in life. Education should humanize humans, realize their potential, and be useful in community. Education becomes a tool of human wisdom in implementing their comprehension about nation and state. Therefore, the importance of character education in the era of industrial revolution 4.0 is very necessary. So that, people can use the technology wisely that will be developed later.

It requires adequate human resources in numbers and quality as the main supports in developing Indonesia. To fulfill those human resources, education has a very important role in it. The National Education System, states that national education functions is to develop capabilities and formthe national characterand civilization in order to educate the life of the nation. National education aims to develop the studentspotential to become human beings who believe to the God, have noble character, healthy, knowledgeable, capable, creative, independent, and become democratic and responsible citizens. 
National education can be achieved through increasing the competency of students attitude, ability (skill), and knowledge. At this time, Indonesia is experiencing a crisis of character values that is characterized by immorality especially in the field of education, it is including where students persecute their teachers, parents of students report and persecute teachers because they do not accept their children being reprimanded, and uncontrolled used of gadgets leading to indecent acts by students.

This reality shows that educational institutions have not succeeded in printing and cementing high moral commitments. As Ubaidillah reports on CNN Indonesia (February 24, 2018), he said that how sophisticated the character education curriculum is applied and taught in the classroom, the moral of students is still untouched which result students persecute their teacher or vice versa.

These problems are contrary to the objectives of the implementation of curriculum 2013 that are improving the quality of educational processes and outcomes thatleadthe noble character of students which are intact, integratedand equal in accordance with graduate competence standard in each education unit. Character education at the level of the education unit leads to the formation of school / madrasah culture, which isthe values that underlie the behavior, tradition, and habits that practiced by school members and community around the school.

Elementary School (SD) as the foundation of formal education must develop the three competencies of students, namely knowledge, attitudes, and skills. For elementary school, the emphasis is developing attitudinal or character competencies that integrated in every subject learnt.

One of the subjects in elementary school that can be integrated with character building in the learning process is Indonesian subjects. Indonesian subjects are one of the main subjects that play an important role in education. Indonesian is not only for developing communication skills but also for the sake of mastering Science and Technology. Indonesian is a science that is very closely related to everyday life and is learned by students early on, for example in communicating or interacting with family and society. Indonesian is expected to be a means to develop thoughts that can create ideas, opinions, feelings. So, they can participate in their social environment. According to(Zulela, 2012), Indonesian learning in elementary is directed in increasing the students ability to communicate well, both verbally and non-verbal, language skills can only be mastered by training through learning. In line with Zulela,(Tarigan, 1985)reveals that language reflects students mind and language skills are obtained through practice, which means also to train thinking skills and character.

Some of the characters that are to be built are related to the general values accepted by society, including honesty, discipline, local wisdom, and cleanliness. The five main character values of the development of the Character Education Strengthening (PPK) movement are sourced from Pancasila, namely religious, nationalism, integrity, independent, and mutual cooperation. PPK encourages the synergy of three education centers, they are schools, families (parents), and the community in order to form an education ecosystem (Kemendikbud, n.d.). Furthermore, through the National Workshop on the Development of Cultural and National Character Education aimed to (1) integrating views on the development of national cultural and character education at every level of education (2) obtaining comprehensive input on the development of national culture and character (3) identifying best experiences/practice in the implementation of the development of national culture and character that can be used as a model (4) formulate the grand design of the nation's cultural and character education at various levels of education (Kemendikbud, 2017). 
Therefore, it is necessary to integrate character education in student learning, especially on Indonesian subjects. Referring to these various opinions, the researchers were interested in researching about "the Integration of Character Education in Learning Indonesian Subject".

\section{Method}

This study uses a descriptive qualitative approach to explore deeply the integration of character education in learning Indonesian subject. The researcher conducted an analysis of various data obtained in the field. Data sources are obtained through documentation, those are Indonesian elementary school books, observation, observing the students behavior in the classroom, and interviewing teachers. The research instrument refers to how to strengthening character education (PPK) of the ministries of education and culture.

\section{Results and Discussion}

Ethimologycally, the term of character originates from the Latin kharakter, kharassaein, and kharax, in Greek the character of the word charassei, which means to make sharp and make in. In English, it is "character" and in Indonesian is commonly used with the term karakter. Depdikdnas (2010) in (Gunawan, 2012)explains that the term character means having character, having personality, having characteristic, and attitude. Individuals who have good or superior character are someone who tries to do good things towards God Almighty, himself, others, environment, nation and state, also worldwide. In general, by optimizing his potential (knowledge) and accompanied by awareness, emotion, and his motivation (feeling).

This is also in line with what was stated by(Aqib, 2012), he stated that based on the study of religious values, social norms, law, academic ethics, and human rights principles, it has been identified items of values that grouped into the main value, they are the values of human behavior in relation to God Almighty, himself, human beings, the environment and nationality. The details of these values are:

1. Relation tothe God, it is religious. The thoughts, words, and actions of a person that is pursued always based on the values of divinity and/or religious teachings.

2. Relation tohimself, which are honest, responsible, healthy life, discipline, hard work, confident, entrepreneurial spirit, logical thinking, critical, creative, and innovative, independent, curious, love of science.

3. Human relationship, which are aware of the rights and obligations of each other, obeying social rules, respecting the peoples work and achievements, polite, and democratic.

4. Relation to the environment, which is caring for the social and the environment are indicated by attitudes and actions that is always striving to prevent damage to the natural environment, and developing efforts to repair the damage to nature that has occurred, and always want to provide assistance to other people and communities in need .

5. National values, which are nationalism and respect for diversity.

The embodiment of individual characters derived from the integration of the four parts of thenation's character in accordance with the philosophy of Pancasila that was developed from theNational Character Development Master Design book (BukuIndukPembangunanKarakterBangsa)2010-2025 (Indonesia, 2010), they are: (1) spiritual and emotional development, which arereligious, grateful, honest, trustworthy, righteous, patient, discipline, law-abiding, responsible, empathic, compassionate, risk-taking, never giving up, respecting the environment, willing to sacrifice, and patriotic, (2) Intellectual 
development, which are smart, creative, innovative, analytic, curious, productive, oriented on science and technology, and reflective, (3) affective and creativity development, that are humanity, mutual respect, mutual love, mutual cooperation, togetherness, friendliness, care, respect, tolerance, nationalism, commitment, prioritizing the public interest, love the country/homeland, proud to use Indonesian language and products, dynamic, hard work, and work ethic, (4) physical and kinesthetic development which are clean and healthy, sportive, firm, reliable, durability, friendly, cooperative, determinative, competitive, cheerful, tenacious, and persistent. (Kemendikbud, 2017).

\section{Indonesian Language Learning}

Indonesian learning is essentially teaching students about Indonesian skills that are good and correct based on its goals and functions. According to(Soewandi, n.d.), the main function of the language is a communication tool for someone. People learn language because it is urged by their need to communicate with people around them. For that reason, in the learning activities, students are required to be able to use good and correct Indonesian for communicating in various situations, which are being able to greet, ask, answer, mention, express opinion and feeling. In communicating, students are also required to use language that reflects character values that relate to the values of human behavior in relation to the God, themselves, human beings, and the environment also values of national characteristics. In addition, Indonesian learning is presented meaningfully as a necessity, which is in the context of its use in communication. The meaningfulness of a sentence relates to the context of its use. An intended context is a reasonable context which is in the interaction between speakers who communicate each other.

Language has a vital role because it is used in daily interactions whether in the school, family/home, and society. Based on research findings, students who understand Indonesian learning can build positive communication with fellow students and teachers. This is in line with the opinion(Abidin, 2012), he states that Indonesian learning is directed at achieving the goals that students must have, which are language skills, language attitude, knowledge of science, Indonesian language ability, self-awareness of the importance of literary works for self-development, and positive response for literary works. The most important thing in learning Indonesian is students are able to communicate and use it in their daily life. Slamet (2007) stated that the main emphasis in learning with a communicative approach is to link the skills of students to communicate with good language. Language is taught as used in communication. Knowledge of language (grammar and vocabulary) is not the goal of learning language. The first thing emphasized is communicative skill. With that communicative skill, students naturally reflect the character values that they embrace as social and cultural creatures.

\section{Character Values Found in Indonesian Learning}

The practice of character education can be implemented if a character-oriented curriculum is available. This is in accordance with the main purpose of learning Indonesian that is to develop human resources that have intellectual and psychomotor on the basics of language. In 
relation to the character education, (Saddhono, Waluyo, \& Raharjo, 2017)quoted Moody in his book The Teaching of Literature. There are four things that can be obtained from learning literature, which are (1) to foster language skills; (2) to train sensitivity and beauty; (3) to be able to live the themes of humanity, morals, noble character (or in other words, the ability to differentiate good and bad things); (4) to understand the character of human, the difference between each other and so that, they try to build solidarity; and (5) to build social sensitivity in the sense of understanding the other's suffering.

The contents of the values implied from literary works in general are religious, moral, social, and ethical, also aesthetic values. In the context of learning Indonesian language and literature, teachers can instill these values through appreciation of literary works. In the learning process, the teacher must convey this, so that students can distinguish between good and bad things.

Based on the observation, there are four basic character values that can be developed. The values developed in character education are identified from various sources as follows:

1. Religion. Indonesian society is a religious community. Therefore, individual, community and nation are always based on religious teachings and beliefs. Politically, the national life is based religious values. Based on those considerations, the values of character education must be based on religious values and religious rules.

2. Pancasila. The Unitary State of the Republic of Indonesia is built on the principles of nationality and statehood calledPacasila. Pancasila is contained in the Preamble of the 1945 Constitution (UUD 1945) and further elaborated in the articles contained in the 1945 Constitution. It means that the values contained in Pancasila become values that govern the political, law, economic, social, cultural and artistic life that are regulated in the articles of the 1945 Constitution. Character education aims to prepare students to become better citizens, which is citizens who have the ability, willingness, and apply Pancasila values in their lives as law-abiding citizens.

3. Culture. It is a truth that there is no human live in a society that is not based on cultural values recognized by the community. Cultural values are used as a basis in giving meaning to a concept and in communication between community members. The position of culture is really important in the life of peoplethat requires the culture to be a source of character education values.

4. National Education Goals. The purpose of national education reflects the quality of people that must be possessed by every Indonesian citizen. It is developed by various educational units at various levels. In the national education goals, there are various humanity values that must be owned by an Indonesian citizen. Therefore, the aim of national education is the most operational source in the development of character education compared to the three sources mentioned above(Kemendikbud, 2017). Based on the four sources of those values, it is identifiedthe number of values for character education.

Based on those opinions, the character education values obtained through Indonesian language learning are, (1) the tolerance attitude reflected in the learning process takes place by respecting peer opinions, (2) mutual cooperation, through positive communication built between teachers and students is able to encourage attitudes in helping each other in school 
activities (3) honest and responsible attitude, the communication skill raises boldness in expressing opinions, and (4) independent, students can complete tasks given independently. When referring to the Ministry of Education and Culture (Kemendikbud) there are five main character values that are the driving forces of character development, they are religious, nationalism, integrity and independence that have aims to form a dynamic and intact personal image(Kemendikbud, 2017)Strengthening character education focuses on the spiritual development(ethics and spirituality), affective and creativity development (esthetics), and sports (kinesthetic) that can be integrated through the intra-curricular, co-curricular, and extracurricular learning processes in the school as the basis for cultural development.

Character education is intended to build students character. The form of the character is values that are seen, both in a universal context and in the context of Indonesian culture, which are values based on national culture. Those values include honesty, righteous, creativity, responsible, discipline, and some others. The values in Indonesian culture that intended including tolerance, mutual cooperation, nationalism and other values that exist in the multilateral layer of Indonesian society. As opinion(Samani, 2012) suggests nine pillars of character education. The nine pillars of character education are; (1) love the god and all of His creations, (2) independent and responsibility, (3) honesty and diplomacy, (4) respect and courtesy, (4) generous, helpful, and cooperate, (5) confidence and hard worker, (6) kind and humble, (7) leadership and justice, (8) tolerance, peace and unity.

\section{The Integration of Character Education in Indonesian Learning}

When referring to the results of previous studies, the results of the analysis showed that character education can be internalized into all subjects without changing the learning material that has been set in the curriculum. There is result of study that internalized the character education into subject, such as civic education, Natural Science, Social Sciences. However, it is different in the context of Indonesian learning which essentially aims to direct students to have good communication skills, both oral and written communication. Communication skill/ability also directs students to build positive communication in the classroom. Therefore, the integration of character education in Indonesian learning is really important, giving students an understanding to other subjects. Based on the findings, there are several media that can be used to foster character in Indonesian learning, it can be described as follows.

a. Through Teaching Materials

Teaching materials commonly used are in the form of literary works or biographies that contain various elements that can be imitated, and also can be through motivational reading book and non-literary works that contain character contents. On the various types of teaching materials used, as a mediator of character education, literary teaching materials are considered as the most appropriate teaching materials. Through literary works, students can find good characters to emulate and then implement it in daily life.

The steps that must be taken by the teacher are (1) choosing teaching materials carefully, (2) determining the type of activities to extract literary works appropriately 
(choosing an appreciation approach), (3) guiding students to explore literary values and moral literary works, (4) doing evaluation results and havingcharacter.

b. Through the Learning Model

The use of learning models as a mediator for character education has also been widely investigated by experts. The research conducted by Budiastuti (TT) showed that the application of character education through dress up practice was able to develop positive character of the student even though there were still many problems faced. (Raka et al., 2011)proved that character education can be applied through PAKEM learning so as to be able to develop the character of students.

The steps that must be taken by the teacher to integrate character education through the learning model are (1) choosing a learning model that is in accordance with the basic competence and core competence in the curriculum, learning objectives, and teaching materials; (2) designing learning steps that can stimulate theemergence of character; (3) doing observations to characterize; (4) evaluating the objectives achieved.

c. Through Authentic Assessment

Authentic assessment is the process of collecting various data that can provide an overview of the learning progress of students. The description of student learning progress is needed throughout the learning process, because this assessment does not do at the end of the period only (end of semester). Assessment activities are carried out coincide with learning activities (Abidin, 2012). (O'malley \& Pierce, 1996) defines the authentic assessment as follows:

"Authentic assessment is an evaluation process that involves multiple forms of performance measurement reflecting the student's learning, achievement, motivation, and attitudes on instructional-relevant activities, Example of authentic assessment techniques include performance assessment, portfolio, and self-assessment".

Based on those understanding, it is very clear that authentic assessments are closely related to efforts to achieve competence. Competence is knowledge, skills, and attitudes that are demonstrated in the habit of thinking and acting in a problem that is faced.(Jhonson, Penny, \& Gordon, 2009) further states that authentic assessment is basically a performance assessment,it means that it is an assessment carried out to find out the knowledge and skills of students during the learning process in achieving certain products or learning outcomes. Activities that will be measured are; (1) observe the picture and make a note of the observations, (2) discuss the characteristics of transportation, (3) compile the essay, (4) report the essay, and (5) revise the essay based on the teacher's advice.

\section{Conclusion}

The integration of character education in Indonesian learning engages an important part that must be prepared in facingthe industrial revolution 4.0 that will have an impact on the students'mentality. Positive communication skills obtained through learning Indonesian are the basic of students'character in acting honestly, responsibly, independently, and tolerance to 
peers, teachers, and the community. This can also encourage the use of technology wisely in the family and school environment. Furthermore, the integration of character education can be carried out through teaching media, learning methods, and authentic assessment.

The integration of character education in learning must be prepared starting from the planning, implementation and evaluation stages. In the preparation stage, all things must be prepared well to support the implementation of character education such as materials, methods, media, learning activities, and evaluations. Those learning components indirectly can help to develop these predetermined type of characters.

\section{Acnknowledgment}

I am extremely grateful to everyone who has participated and contribute in finishing this research, so this research can be done well. Everyonewho helps me provided any reference sources. Especially, thanks to the leader of LP2M who gave me permission to do a research. Thanks to the chief of FIP UNM who gave me donation that are PNBP 2019 to do my research. Also my colleagues (DrsAbd. Hafid, M.Pd and Dr. Rukayah, M.Pd) who had helped me conducting my research and PGSD students who had participated to.

\section{Reference}

Abidin, Y. (2012). Pembelajaran bahasa berbasis pendidikan karakter. Refika Aditama.

Aqib, Z. (2012). Pendidikan Karakter di sekolah membangun karakter dan kepribadian anak. Bandung: Yrama Widya.

Gunawan, H. (2012). Pendidikan karakter: konsep dan implementasi. Alfabeta.

Indonesia, P. R. (2010). Desain Induk Pembangunan Karakter Bangsa. Tahun.

Jhonson, R. L., Penny, J. A., \& Gordon, B. (2009). Assessing Performance. Designing, Scoring, and Validating Performance Tasks. London: Guilford Press.

Kemendikbud, R. I. (2017). Konsep dan Pedoman Penguatan Pendidikan Karakter. Kementrian Pendidikan Dan Kebudayaan Republik Indonesia. Jakarta.

O'malley, J. M., \& Pierce, L. V. (1996). Authentic assessment for English language learners: Practical approaches for teachers. Addison-Wesley Publishing Company New York.

Raka, G., Mulyana, Y., Markam, S. S., Semiawan, C. R., Hasan, S. H., Bastaman, H. D., \& Nurachman, N. (2011). Pendidikan karakter di sekolah: Dari gagasan ke tindakan. Jakarta: PT Gramedia.

Saddhono, K., Waluyo, H. J., \& Raharjo, Y. M. (2017). Kajian Sosiologi Sastra Dan Pendidikan Karakter Dalam Novel Nun Pada Sebuah Cermin Karya Afifah Afra Serta Relevansinya Dengan Materi Ajar di SMA. JPI (Jurnal Pendidikan Indonesia), 6(1), $16-27$.

Samani, M. (2012). Hariyanto. 2012. Konsep Dan Model Pendidikan Karakter, 2.

Soewandi, A. M. (n.d.). Slamet. 2007. Handout Penelitian Pendidikan Bahasa Dan Sastra Indonesia.

Tarigan, H. G. (1985). PERANAN KOSA KATA: DALAM BUKU PELAJARAN BAHASA SEKOLAH DASAR. In Seminar Penulisan Bahan Pengajaran Bahasa, Yogyakarta, 30 Mei-4 Juni 1983 (Vol. 85, p. 108). Pusat Pembinaan dan Pengembangan Bahasa, Departemen Pendidikan dan Kebudayaan.

Zulela, M. S. (2012). Pembelajaran Bahasa Indonesia Apresiasi Sastra di Sekolah Dasar. 
Bandung: Remaja Rosdakarya. 